\title{
Analisis Kelayakan Finansial Industri Tempe di Kelurahan Oelami Kecamatan Bikomi Selatan
}

Adeline Norawati Hutapea ${ }^{a}$, Yosefina Marice Fallo ${ }^{b}$

${ }^{a}$ Fakultas Pertanian, Universitas Timor, Kefamenanu, Indonesia.

${ }^{b}$ Fakultas Pertanian, Universitas Timor, Kefamenanu, Indonesia.

\section{Article Info}

Article history:

Received 18 November 2016

Received in revised form 24 November 2016 Accepted 7 Januari 2017

\section{Keywords:}

Kelayakan Finansial

Tempe

Oelam

Bikomi Selatan

\section{Abstrak}

Penelitian ini bertujuan menganalisis kelayakan finansial industri kecil tempe di Kelurahan Oelami Kecamatan Bikomi Selatan Kabupaten Timor Tengah Utara tahun 2015. Penelitian menggunakan metode deskriptif analitis dan menggunakan data primer dan data sekunder. berupa modal, tenaga kerja, bahan baku, teknologi, produksi, pemasaran dan kelayakan finansial dengan teknik sampling sensus. Analisis kelayakan investasi menggunakan analisis Net Present Value (NPV), dan untuk mengetahui industri kecil tempe layak atau tidak untuk terus dijalankan menggunakan analisis Benefit Cost Ratio (BCR), sedangkan analisis Internal Rate of Return (IRR) untuk mengetahu kelayakan investasi dan operasional industri tempe. Hasil penelitian menunjukkan nilai BCR $(1,1)>1$, artinya industri tempe layak dilanjutkan, dan nilai NPV positif (+) menunjukkan industri tempe tersebut layak dilakukan investasi. Sedangkan nilai IRR (30,3519\%) > bunga pinjaman $(\mathrm{DF}=18 \%)$ menunjukkan industri tempe di Kelurahan Oelami layak untuk dilakukan investasi dan menjalankan operasional perusahaan dan Break Event Point (BEP) sebesar 180.496 unit/tahun. Dengan demikian industri kecil tempe bisa dikembangkan karena memberikan potensi keuntungan. (2017 dipublikasikan oleh Agrimor.

\section{Pendahuluan}

Industri kecil memiliki peran yang cukup strategis dalam menggerakkan perekonomian. Salah satu industri kecil yang potensial untuk dikembangkan di Kabupaten Timor Tengah Utara (TTU) adalah industri tempe. Sebagai produk industri olahan berbasis pertanian, tempe memiliki keunggulan terutama kandungan proteinnya yang tinggi, selain itu harganya jauh lebih murah dibandingkan dengan protein hewani.

Seiring menurunnya daya beli masyarakat, menjadikan tempe sebagai alternatif pilihan konsumen untuk memenuhi kebutuhan gizinya. Sehingga, tingginya permintaan tempe di TTU membuka peluang bagi pengembangan industri olahan produk pertanian tersebut.

Sampai saat ini belum ada data yang pasti tentang tingkat konsumsi tempe masyarakat di TTU. Namun, berdasarkan fenomena di lapangan memperlihatkan bahwa akhir-akhir ini jumlah penjual dan produsen tempe mengalami tren yang semakin meningkat dengan jumlah produksi yang semakin banyak dari tahun ke tahun. Dari aspek hukum penawaran dan permintaan, hal ini sebenarnya menunjukkan adanya fenomena bahwa permintaan tempe di Kota Kefamenanu dan sekitarnya terus mengalami peningkatan.

Untuk itu, perlu adanya suatu kajian terhadap kelayakan finansial industri tempe untuk melihat kemungkinan tingkat keberhasilan dari investasi usaha yang relatif baru bagi masyarakat TTU. Sehingga, analisis kelayakan ini akan memberikan informasi sebagai dasar pertimbangan baik dari aspek teknis, ekonomis, dan komersial untuk memutuskan apakah investasi usaha tempe bisa dikembangkan atau tidak bagi pengambilan keputusan investasi.

Penelitian ini secara spesifik hendak menganalisis kelayakan usaha tempe di Kelurahan Oelami, Kecamatan Bikomi Selatan ditinjau dari aspek keuangan (financial).

\section{Metode}

Penelitian menggunakan metode descriptive analysis sebagaimana menuru Singarimbun dan Effendi, (1982) adalah meneliti suatu objek pada masa sekarang atau sekurang-kurangnya jangka waktu yang masih terjangkau dalam ingatan responden, atau pengukuran secara cermat terhadap fenomena sosial tertentu. Data yang diperoleh di lapangan disusun, dianalisis, dan dijelaskan sehingga didapatkan penjelasan mengenai fenomena-fenomena yang terjadi.

Pengambilan sampel dilakukan secara sensus maka keseluruhan populas sebanyak 12 pengusaha tempe dijadikan sebagai responden. Data penelitian in meliputi data primer dan data sekunder. Data primer diperoleh langsung dari lapangan, dengan wawancara dan pengamatan langsung di lapangan. Sedangkan data sekunder berupa sumber-sumber bacaan seperti surat-surat, notula rapat, atau dokumen-dokumen resmi pemerintah, yang didapatkan dari perpustakaan dan instansi pemerintah yang dapat mendukung penelitian (Nasution, 2012).

Variabel dalam penelitian ini meliputi modal, tenaga kerja, bahan baku, teknologi, produksi, pemasaran dan kelayakan finansial. Kelayakan usaha dianalisis menggunakan analisis kelayakan finansial sesuai petunjuk (Firdaus, 2012; Hernanto, 1991; Obst et al., 2007).

\section{Hasil dan Pembahasan}

\subsection{Gambaran Umum Industri Tempe}

Berdasarkan penelusuran di lapangan menunjukkan bahwa jumlah industri kecil tempe pada tahun 2015 di Kelurahan Oelami sebanyak 12 pengusaha Karakteristik industri kecil tempe di Kelurahan Oelami seluruhnya merupakan industri rumah tangga, sehingga kepemilikannya melekat pada kepala keluarga Sebagian besar pengusaha tempe berusia antara 31 - 40 tahun $(58,3 \%)$, pengusaha yang memiliki rentang usia 20 - 30 tahun sebanyak 3 orang $(25 \%)$, sedangkan pengusaha yang berusia antara $41-50$ tahun sebanyak 2 orang $(16,7 \%)$

Pengusaha kecil tempe paling banyak berpendidikan SMP yaitu sebanyak 7 orang $(58,3 \%)$, pengusaha yang memiliki pendidikan SMA sebanyak 5 orang $(41,7 \%)$. Kepemilikan usaha pada industri kecil tempe di Kelurahan Oelam seluruhnya merupakan milik sendiri, artinya bahwa industri kecil tempe di
Kelurahan Oelami tidak ada yang berstatus usaha bersama atau patungan dari beberapa orang. Sebanyak lima orang pengusaha $(41,7 \%)$ telah mendirikan usaha indusri kecil tempe selama kurang lebih empat tahun. Sedangkan pengusaha industri kecil tempe yang telah berusaha selama kurang lebih lima tahun dan tujuh tahun masing-masing sebanyak tiga orang pengusaha, dan sebanyak satu orang pengusaha $(8,3 \%)$ baru mendirikan usahanya selama satu tahun berjalan.

Modal industri kecil tempe antara Rp. 510.000-Rp. 800.000 sebanyak lima orang $(41,6 \%)$, sedangkan yang memulai usaha dengan modal awal antara $\mathrm{Rp}$. 100.000-Rp. 300.000 dan antara Rp. 310.000-Rp. 500.000 masing-masing sebanyak dua pengusaha $(16,7 \%)$, dan terdapat tiga pengusaha kecil $(25 \%)$ yang memulai usaha dengan modal awal berkisar antara Rp. 810.000-Rp.1.000.000 Sedangkan sumber modal awal, seluruhnya berasal dari modal sendiri.

Asal tenaga kerja pada industri kecil tempe di Kelurahan Oelami berasal dari anggota keluarga sebanyak tujuh pengusaha $(58,7 \%)$, dan yang berasal dar saudara sebanyak tiga pengusaha $(25 \%)$, sedangkan sebanyak dua pengusaha $(16,7 \%)$ memiliki tenaga kerja yang berasal dari tetangga sekitar. Sebanyak enam pengusaha $(50 \%)$ memiliki tenaga kerja antara 3-4 orang, empat pengusaha $(33,4 \%)$ memiliki jumlah tenaga kerja antara 1-2 orang, sedangkan yang memiliki jumlah tenaga kerja antara 5-6 orang dan lebih dari enam orang masingmasing sebanyak satu pengusaha.

Bahan baku yang digunakan pada industri tempe di Kelurahan Oelami seluruhnya diperoleh dengan cara membeli di toko-toko di Kota Kefamenanu. Hal ini disebabkan mereka masih belum memiliki mitra bisnis yang berfungsi sebagai pemasok kedelai secara rutin. Para pengusaha tempe seluruhnya masih memanfaatkan teknologi tradisional.

Pesaing utama dalam pemasaran pada industri tempe di Kelurahan Oelami berasal dari perusahaan sejenis yang berada di Kota Kefamenanu. Hal in berdasarkan pada asumsi; 1) Memiliki pengalaman lebih lama, sehingga lebih dikenal oleh masyarakat Kota Kefamenanu, 2) Jumlah modal relatif lebih besar, sehingga jumlah produksi juga lebih besar, 3) Lebih terampil, karena kebanyakan pengusaha tempe berasal dari Jawa, 4) Akses kepada konsumen (pasar) lebih luas, sehingga menjadi tantangan tersendiri bagi pengusaha tempe di Kelurahan Oelami dalam memasarkan produknya.

Jenis produk pada industri tempe di Kelurahan Oelami adalah jenis produk tempe dengan menggunakan bungkus plastik. Hal ini disebabkan bahwa dengan menggunakan plastik sebagai pembungkus tempe dengan alasan lebih mudah memasukkan kedelai ke dalam bungkus plastik, sehingga dalam memperoduks tempe lebih efektif dan efisien. Daerah pemasaran pada industri tempe di Kelurahan memasarkan produknya ke Kota Kefamenanu, beberapa diantaranya sampai ke Noemuti dan Maubesi, bahkan dua pengusaha tempe telah memiliki pelanggan tetap sampai ke Wini dan masyarakat di daerah perbatasan.

Dalam tiga tahun terakhir ini terdapat lima pengusaha tempe baru. Hal in menunjukkan bahwa industri kecil tempe menjadi salah satu primadona industri berbasis keluarga bagi masyarakat di Kelurahan Oelami, karena secara ekonomis industri ini cukup menjanjikan.

Walaupun memiliki prospek ekonomis, ternyata seluruh pengusaha tempe tersebut belum memanfaatkan teknologi modern dalam proses produksinya. Misalnya, dalam proses pembersihan kedelai masih ditampi secara manual. Selanjutnya kedelai dicuci dan direbus diatas kayu bakar, setelah itu ditriskan dan direndam dalam air selama satu malam, gunanya untuk memisahkan kulit arinya dari biji kedelai. Esok harinya, kedelai dicuci di sungai untuk memisahkan kulit dengan biji kedelai, setelah bersih kedelai kembali kedelai dicuci dengan air panas supaya higienis. Selanjutnya kedelai ditaburi ragi dan diaduk sampai rata sambil diangin-anginkan. Setelah ragi tercampur dengan rata selanjutnya masuk tahap pengemasan.Pada tahap pengemasan mereka masih menggunakan lampu pelita untuk merekatkan plastik pembungkus tempe, karena memang jenis produk mereka seluruhnya adalah tempe dengan kemasan plastik, tidak ada yang menggunakan kemasan daun. Seluruh tahapan pembuatan tempe tersebut masih dilakukan secara manual.

Sedangkan menyangkut asal bahan baku, seluruh pengusaha tempe tersebut membeli dari toko di Kota Kefamenanu, sampai dengan saat penelitian belum 
satupun pengusaha yang memiliki mitra sebagai pemasok tetap kedelai. Kondisi ini akan berpengaruh pada kontinuitas ketersediaan kedelai dan stabilitas harga kedelai. Fluktuasi harga kedelai tersebut akan berpengaruh pada besaran biaya variabel.

Patut diapresiasi bahwa ternyata para pengusaha tempe di Oelami tidak hanya memasarkan produknya di sekitar wilayah Oelami, namun telah menembus sampai ke Kota Kefamenanubahkan dua pengusaha tempe setempat memasarkan produk tempe sampai ke Noemuti, Maubesi dan Wini. Khusus untuk konsumen di Kota Kefamenanu rata-rata mereka telah memiliki pangsa pasar tersendiri, baik kalangan rumah tangga maupun rumah makan, bahkan beberapa diantaranya rela untuk datang langsung ke perusahaan untuk membeli tempe, karena telah menjadi pelanggan tetap.

Berdasarkan gambaran pemasaran tempe tersebut, sebenarnya menunjukkan bahwa pengusaha tempe dari Kelurahan Oelami bisa bersaing dengan produsen tempe dari Kota Kefamenanu. Hal ini tidak terlepas dari kualitas produk tempe yang mereka hasilkan. Berdasarkan penelusuran di lapangan, produk tempe dari Oelami ternyata memiliki keunggulan dibandingkan dengan tempe hasil produksi pengusaha di Kefamenanu, keunggulan tersebut adalah; 1) menyangkut tingkat kebersihan tempe, tempe produk sentra industri tempe Kelurahan Oelami relatif bersih tidak ada kotoran berupa serpihan kayu maupun kerikil, 2) tidak ada bahan campuran berupa tepung, beberapa produsen tempe di Kefamenanu berdasarkan hasil pemeriksaan Dinas Kesehatan TTU positif menggunakan campuran tepung terigu supaya tempe terlihat lebih putih, dan 3) tidak menggunakan campuran jagung untuk mengurangi bahan baku kedelai. Ketiga keunggulan tersebut yang menjadikan tempe produk sentra industri Kelurahan Oelami tetap eksis karena dapat bersaing dengan industri sejenis dari Kota Kefamenanu.

\subsection{Analisis Kelayakan Finasial}

Biaya tetap para pengusaha tempe di Kelurahan Oelami meliputi biaya yang dialokasikan untuk pembelian berbagai peralatan penunjang operasional. Dengan demikian, biaya tetap disebut juga sebagai biaya inventaris. Berdasarkan data lapangan menunjukkan bahwa besarnya biaya tetap yang dikeluarkan oleh para pengusaha tempe di Kelurahan Oelami sebesar Rp. 72.000.000. Biaya sebesar itu rata-rata dialokasikan untuk pembelian peralatan operasional, instalasi listrik, instalasi air, penambahan ruang khusus untuk kegiatan produksi tempe dan pembuatan bak penampung air, dan lain-lain.

Berdasarkan data yang diperoleh di lapangan menunjukkan bahwa variabel produksi tempe di Kelurahan Oelami untuk total biaya per hari sebesar Rp. 3.585.000, dan total biaya per bulan sebesar Rp. 71.700.000, sedangkan jumlah biaya per tahun sebesar Rp. 860.400 .000 .

Data di lapangan hasil pendapatan tiap unit/bungkus tempe di Kelurahan Oelami adalah 1) Produksi tempe tiap hari $=1.707$ unit (bungkus); 2) Produksi tempe tiap bulan $=34.125$ unit (bungkus); 3) Produksi tempe tiap tahun $=$ 409.500 unit (bungkus); 4) Harga penjualan/unit = Rp. 2.500; 5) Total penerimaan $/$ tahun $=$ Rp. 1.023.750.000, dan; 6) Total Pendapatan $/ \operatorname{tahun}=\mathrm{Rp}$. 91.350. 000 .

Arus kas produksi tempe pada industri kecil tempe di Kelurahan Oelami menunjukkan rata-rata pendapatan para pengusaha tempe di Kelurahan Oelami mengalami fluktuasi setiap tahunnya, yaitu berkisar antara Rp. 40.000.000 sampai dengan Rp. 42.000.000. Hal tersebut karena dipengaruhi oleh fluktuasi biaya dan penerimaan setiap tahunnya.

\section{a. $\quad$ Net Present Value (NPV)}

Net Present Value (NPV) atau nilai uang sekarang industri tempe di Kelurahan Oelami berdasarkan suku bunga pinjaman bank sebesar $18 \%$, menunjukkan nilai NPV positif, dengan demikian industri tempe di Keluarahan Oelami secara finansial layak untuk dilakukan investasi.

b. Internal Rate of Return (IRR)

Internal Rate of Return (IRR) merupakan tingkat bunga yang menyamakan nilai sekarang aliran kas masuk dengan nilai investasi. Berdasarkan perhitungan, nilai IRR adalah $30,3519 \%$. Karena nilai IRR $(30,3519 \%)>$ bunga pinjaman (18\%) sehingga para pengusaha tempe di Kelurahan Oelami layak untuk melakukan investasi dan menjalankan perusahaan tempe mereka.

c. Benefit Cost Ratio (BCR)

Benefit Cost Ratio (BCR) merupakan perbandingan penerimaan dan biaya, berdasarkan perhitungan nilai BCR sebesar 1,1. Karena nilai BCR > 1, maka usaha tempe di Kelurahan Oelami layak untuk terus dijalankan.

d. Break Event Point (BEP)

Berdasarkan perhitungan, Break Event Ponit (BEP) sebesar 180.496 unit/tahun, sehingga industri tempe di Kelurahan Oelami akan mencapai titik impas jika mereka memproduksi tempe sebanyak 180.496 unit/tahun. Dengan demikian, untuk memperoleh keuntungan mereka harus memproduksi tempe diatas titik impas.

Pada dasarnya setiap usaha atau industri membutuhkan dana untuk kelangsungan dan keberlanjutan industri tersebut, baik untuk pembiayaan proses produksi maupun investasi. Pada kasus tertentu, walaupun suatu perusahaan sudah beroperasi sekian lama ternyata tidak menguntungkan secara finansial, sehingga tidak layak untuk dilanjutkan. Berdasarkan pemikiran tersebut, perlu ada suatu kajian tentang kelayakan finansial untuk meninjau kembali apakah suatu perusahaan layak atau tidak untuk terus diusahakan.
Berdasarkan hasil perhitungan analisis kelayakan usaha tempe di Kelurahan Oelami nilai Net Present Value (NPV) sebesar Rp. 96.717.999,2658. Hal ini memiliki arti bahwa ternyata nilai NPV > 0, dengan demikian industri tempe di Kelurahan Oelami layak untuk terus diusahakan dan pengusaha tempe setempat maupun calon pengusaha tempe yang berminat membuka usaha tempe secara finansial layak melakukan investasi.

Tingkat bunga yang menyamakan nilai sekarang aliran kas masuk dengan nilai investasi atau Internal Rate of Return (IRR) memiliki nilai sebesar 30,3519. Hal ini menunjukkan bahwa nilai IRR $(30,3519 \%)>$ tingkat bunga pinjaman bank $(\mathrm{DF}=18 \%)$, sehingga para pengusaha tempe di Kelurahan Oelami layak untuk melakukan investasi untuk pengembangan usaha dan layak untuk terus menjalankan perusahaan tempe mereka.

Nilai Benefit Cost Ratio (B/C R) merupakan perbandingan antara nilai sekarang arus manfaat yang bernilai positif dengan nilai sekarang arus manfaat yang bernilai negatif. Berdasarkan perhitungan nilai B/C R besarnya 1,1. Karena nilai B/C R > 1 atau positif, maka usaha atau industri tempe di Kelurahan Oelami layak untuk dilaksanakan dan dilanjutkan.

Berdasarkan penghitungan, nilai Break Event Point (BEP) sebesar 180.496 unit/tahun. Hal ini berarti bahwa industri tempe di Kelurahan Oelami akan mencapai titik impas jika mereka memproduksi tempe sebanyak 180.496 unit per tahun. Sehingga untuk memperoleh keuntungan mereka harus memproduksi tempe diatas titik impas, sebaliknya jika produksi mereka dibawah 180.496 unit per tahun maka mereka akan mengalami kerugian finansial.

Berdasarkan analisis kelayakan finansial tersebut, maka dalam penelitian ini dapat disimpulkan bahwa usaha industri tempe di Kelurahan Oelami layak terus dilaksanakan bahkan bisa dilakukan investasi untuk pengembangan perusahaan tempe tersebut.

\section{Simpulan}

Industri tempe di Kelurahan Oelami seluruhnya merupakan usaha dengan status milik sendiri yang dikelola keluarga, sehingga tenaga kerja sebagian besa berasal dari internal keluarga maupun saudara. Dalam mendirikan usahanya, mereka menggunakan modal sendiri, rata-rata mereka telah berusaha selama 3 8 tahun dan sampai saat ini masih bisa bertahan karena komitmen yang mereka bangun, yaitu untuk mempertahankan kualitas produk dan menetapan harga yang bisa bersaing dengan perusahaan sejenis di Kota Kefamenanu. Berdasarkan analisis finansial, industri tempe di Kelurahan Oelami layak untuk terus diusahakan bahkan bisa dikembangkan dengan menambah investasi. Hal in dibuktikan berdasarkan perhitungan nilai Net Present Value (NPV) $>0$ atau sebesar Rp. 96.717.999,2658, dan Internal Rate of Return (IRR) memiliki nilai sebesar 30,3519 atau nilai IRR (30,3519\%) > DF sebesar 18\%, sedangkan nilai Benefit Cost Ratio (B/C R) sebesar 1,1 atau B/C R > 1, sehingga usaha atau industri tempe di Kelurahan Oelami layak untuk dilaksanakan dan dilanjutkan. Sedangkan nilai Break Event Point (BEP) sebesar 180.496 unit/tahun atau industri tempe di Kelurahan Oelami akan mencapai titik impas jika mereka memproduksi tempe sebanyak 180.496 unit per tahun, dan sampai saat in produksi tempe dari sentra industri tempe di Kelurahan Oelami rata-rata bisa mencapai produksi 409.500 unit per tahun.

\section{Pustaka}

Firdaus, M., 2012. Manajemen Agribisnis. Bumi Aksara, Jakarta

Hernanto, F., 1991. Ilmu Usahatani. Penebar Swadaya.

Nasution, S., 2012. Metode Research. Bumi Aksara, Jakarta.

Obst, W.J., Graham, R., Christie, G., 2007. Financial Management for Agribusiness. Landlinks Press.

Singarimbun, M., Effendi, S., 1982. Metode Penelitian Survei. Lembaga

Penelitian Pendidikan dan Penerangan Ekonomi dan Sosial (LP3ES). 